\title{
El urbanismo humanista y la "policía española" en el Nuevo Reino de Granada, siglo XVI
}

Carlos José Suárez García*

\section{RESUMEN}

El proyecto urbano europeo que se desarrolló durante el siglo XVI en América estaba fundamentado en la ciudad como la mayor expresión de la civilización occidental. Este articulo presenta la genealogía urbana de los "pueblos de indios" construidos para concentrar a los indígenas y enseñarles la religión católica. El desarrollo de las formas puede trazarse mediante la comparación de diversos tratados urbanos considerados "humanistas", que muestran a la ciudad como un medio para la expresión de comportamientos específicos; así, la ciudad era un espacio pedagógico y emocional para controlar la población indígena. Como práctica de buen gobierno, los "pueblos de indios" condensaban materialmente los principios de la "policía española”. Además de la origen "humanista” de los pueblos impuestos en América, este proyecto buscaba homogeneizar las creencias y comportamientos de los indígenas.

Palabras clave: "Pueblos de indios"; urbanismo colonial; doctrina católica.

\section{ABSTRACT}

The European urban project established in America during the sixteenth-century deemed the city as the highest expression of civilization. This article shows the urban genealogy of the American "pueblos de indios" (Indian villages), built to concentrate the native population, and to teach them the Catholic doctrine. The urban form could be traced by comparing several architectural treatises considered "humanistic" that show the city as a medium to express a specific behavior; thus, the city was a pedagogical and emotional space to control the indigenous population. As a practice of good governance, the "pueblos de indios" materially condensed the "Spanish police" principles. Besides the humanistic background of the towns imposed in America, the project sought to homogenize the natives' behavior and beliefs.

Keywords: "pueblos de indios"; Colonial urbanism; Catholic doctrine.

Artículo recibido em 23 de junio de 2014 y aprobado en 29 de diciembre de 2014.

DOI - http://dx.doi.org/10.1590/2237-101X016030005

Investigación financiada por CNPq (2011) y por Faperj (2012).

* Maestro en Planeación Urbana y Regional de la Universidad Federal de Rio de Janeiro (UFRJ), e investigador del Centro de Estudios Sociales (CES) de la Universidad Nacional de Colombia. Bogotá D.C., Colombia. E-mail: cjsuarezg@unal.edu.co 
Durante la primera mitad del siglo XVI se fundaron las "ciudades de españoles" y las actuales capitales de Hispanoamérica, sobre las bases de una larga tradición urbanística europea; en la segunda mitad predominó una política de concentración de los nativos en "pueblos de indios". ${ }^{1}$ Propongo estudiar en este artículo la genealogía de las formas urbanas para la concentración de los indígenas y su relación con los discursos morales y la "policía urbana”. La genealogía de la ciudad ideal que se impuso en el Nuevo Reino de Granada se puede rastrear hasta el siglo XIV con las obras de pensadores "humanistas" como Francesc Eiximenic, Rodrigo Sánchez de Arévalo, León Bautista Alberti y Pietro Cataneo. Las influencias formales del urbanismo "humanista" europeo aparecen en el proyecto español, especialmente en las Ordenanzas de Felipe II de 1573, donde se reforzaba el carácter evangelizador de los "pueblos de indios". Las interpretaciones locales de las Reales Cédulas y Ordenanzas promulgadas durante el siglo XVI se reflejaban en los Acuerdos de la Real Audiencia de Santafé y las obras de los primeros obispos del Nuevo Reino de Granada, los franciscanos Juan de los Barrios y Luis Zapata de Cárdenas. Finalmente, las Visitas a la Provincia de Tunja, efectuadas por el oidor Luis Henríquez entre 1598 y 1605, consolidaron el nuevo orden territorial mediante la nucleación y conformación de veinticuatro "pueblos de indios", los cuales persisten en la actualidad.

Si bien la definición del término "policía" no se estableció formalmente hasta 1611 en el diccionario de Covarrubias como la vida urbana y la política, ${ }^{2}$ en los documentos españoles del siglo XVI la expresión "vivir en policía" definía el buen gobierno y justicia de los indígenas. El fraile agustino Jerónimo Román y Zamora (1536-1597) definió la "policía" en su texto República de Indias, idolatrías y gobierno en México y Perú Antes de la Conquista (1575) como una virtud del príncipe observable en todas las sociedades:

Las buenas leyes dos efectos solamente pretenden inducir en la policía: el uno es enderezar a todo hombre y miembro de ella, como se debe haber con toda la comunidad y Republica, y en cualquier persona della, haciendo bien. Y el segundo es impedir que los hombres se abstengan de hacer mal y de toda injuria a toda la comunidad y a cualquier parte o miembro della. ${ }^{3}$

\footnotetext{
${ }^{1}$ MORSE, Richard. A evolução das cidades latino-americanas. Cadernos CEBRAP, São Paulo, n. 22, 1975; MORSE, Richard. A prolegomenom to Latin America urban history. The Hispanic American Historical Review, Durham, v. 52, n. 3, p. 359-394, 1972; ROMERO, José Luis. América Latina, as cidades e as idéias. Rio de Janeiro: Editora UFRJ, 2009.

${ }^{2}$ COVARRUBIAS, Sebastián. Tesoro de la lengua castellana, o española. Madridd: Luis Sánchez impressor, 1611: "Termino ciudadano y cortesano. Consejo de policía, el que gobierna las cosas menudas de la ciudad, y el adorno della y limpieza. Politico, el urbano y cortesano. Politica, la ciencia y modo de gobernar la ciudad y republica”. p. 1.221.

${ }^{3}$ ROMÁN, Jerónimo. Repúblicas de Indias idolatrías y gobierno en México y Perú antes de la conquista. Madridd: Victoriano Suárez editor, 1897, t. 1, p. 275.
} 
Este cronista observó que las sociedades indígenas de México y Perú castigaban duramente el adulterio pero toleraban la mancebía entre solteros como prácticas de buena "policía". Ésta denotaba también el cuidado en el trabajo y el buen orden en el mercado, virtudes excelsas que poseían los indígenas del Perú:

Presidía este mercado un juez, el cual miraba que nadie se hiciese agravio, y tasaba los precios, y el conocía de cualquier cosa que acaeciese en el mercado. En esta provincia habia mucha policia, porque allí habia plateros y pintores; y maestros de labrar cosas de plumas; las mujeres sabian hilar, tejer, y otras cosas que pertencen a las mujeres. Eran leyes muy santas y buenas, que si las quisieramos comparar a muchas de las nuestras, no discreparíamos mucho. ${ }^{4}$

Estas costumbres "virtuosas" observadas por los primeros cronistas podían ser preservadas por la Corona, como aparece en la Real Cédula del 6 de agosto de 1555: "Mandamos que las leyes y buenas costumbres que antiguamente tenían los indios para su buen gobierno y policía, y sus usos y costumbres sean observadas y guardadas después que son cristianos".5 Como virtud de orden, buen gobierno y harmonía de los habitantes, la "policía" se contraponía a la holgazanería, como estipulaba la Real Cédula del 18 de enero de $1552 .{ }^{6}$ Joseph de Acosta (1540-1600) dividió en dos su Historia Natural y Moral de las Indias (1590): superstición, ritos, idolatrías y sacrificios y policía, gobierno, leyes, costumbres y hechos. ${ }^{7} \mathrm{La}$ oposición entre la "policía" y la "barbarie" describía diferentes niveles de orden social entre los indígenas, iniciando por los más salvajes que vivían esparcidos:

Hoy día hay en Nueva España de este género de gente, que viven de su arco y flechas, y son muy perjudiciales, porque para hacer mal y saltear se acaudillan y juntan, y no han podido los Españoles, por bien ni mal, por maña ni fuerza, reducirlos á policía y obediencia, porque como no tienen pueblos, ni asiento, el pelear con éstos es puramente montear fieras, que se esparcen y esconden por lo mas áspero y encubierto de la sierra: tal es el modo de vivir de muchas Provincias hoy día en diversas partes de Indias. ${ }^{8}$

Ya que la "policía" fue impuesta compulsiva y exhaustivamente por los españoles, los indígenas cambiaron paulatinamente sus costumbres, como lo describió Acosta:

\footnotetext{
${ }^{4}$ Ibid., p. 306-307.

${ }^{5}$ PAREDES, Julián de. Recopilación de las Leyes de los Reinos de las Indias. Madridd, 1681, Libro II, título I, ley iiii.

${ }^{6}$ Ibid., Libro II, título XXXI, ley ix.

${ }^{7}$ ACOSTA, Joseph de. Historia Natural y Moral de las Indias. Madridd: Ramón Anglés, 1894, t. 2, p. ix.

${ }^{8}$ Ibid., p. 233.
} 
Los bárbaros Chichimécos, viendo lo que pasaba, comenzaron á tener alguna policía, y cubrir sus carnes, y hacérseles vergonzoso lo que hasta entonces no lo era, y tratando ya con esotra gente, y con la comunicación perdiéndoles el miedo, fueron aprendiendo de ellos, y ya hacían sus chozas y buhíos, y tenían algún orden de República, eligiendo sus Señores, y reconociéndoles superioridad. Y así salieron en gran parte de aquella vida bestial que tenían; pero siempre en los montes y llegados á las sierras, y apartados de los demás.?

Tanto Román y Zamora como Acosta pretendían mostrar la existencia de leyes y policía entre los indígenas Nueva España y del Perú que no contravenían el orden español cristiano podrían someterse fácilmente a la Corona mediante la doctrina sin necesidad de la violencia. En el "Epítome de la conquista del Nuevo Reino de Granada" se menciona el término de "policía" ligada al orden dentro de la nación muisca, en especial los castigos por matar y hurtar. ${ }^{10}$ Las connotaciones de buen orden urbano, la cortesía en el trato y las costumbres, así como el aseo, belleza y pulidez ligadas al término policía persistieron hasta el siglo XVIII. ${ }^{11}$

La "policía urbana” que se desarrolló en Espańa desde el siglo XIII respondía al cuidado y regulación del orden urbano, del comportamientos y de la forma de la ciudad. ${ }^{12}$ Definía el buen gobierno de las personas y se configuraba dentro del espacio urbano, en oposición al ocio, la dispersión y las costumbres "bárbaras”. Esta concepción amplia se incorporó en las Ordenanzas del siglo XVI como modos de organizar a los nuevos paganos y someterlos a la religión católica. Así, la imposición de la religión, la ordenación territorial y la trama urbana funcional se expresaban simultáneamente al iniciar la Colonia. ${ }^{13}$

\section{Concentrar para evangelizar: modos pacíficos de sumisión}

Tras el descubrimiento del Nuevo Mundo, la legislación de las Indias del siglo XVI dio privilegios a los conquistadores mediante el sistema de "encomiendas" o "repartimientos", que se estableció como el medio conversión espiritual de los indígenas al catolicismo y que se convirtió en el modo de dominación y de extracción del tributo. En la Real Cédula del 14 de agosto de 1509, el rey Fernando de Aragón dio las siguientes instrucciones a los adelantados para iniciar el proceso de catequización: "Que cada uno se encargue de los que fueren de su repartimiento y los defienda y ampare, proveyendo ministros que les enseńen la doctrina

\footnotetext{
${ }^{9}$ Ibid., p. 239.

${ }^{10}$ FRIEDE, Juan. Descubrimiento del Nuevo Reino de Granada y Fundación de Bogotá (1536-1539). Bogotá: Imprenta del Banco de la República, 1960a.

${ }^{11}$ DICCIONARIO DE AUTORIDADES, t. V, 1737.

${ }^{12}$ ANGUITA, Ricardo. Ordenanza y policía urbana, orígenes de la reglamentación edificatoria en España. Granada: Universidad de Granada, 1997.

${ }^{13}$ FRAILE, Pedro. "Razón, estado, ciudad y territorio: de Sinapia a Valentin de Foronda". Scripta Nova, Barcelona, v. 16, n. 418 (17), s/p, nov. 2012.
} 
cristiana, y administren los sacramentos guardando Nuestro Patronazgo y enseñen a vivir en policía”. ${ }^{14}$ Como complemento, el testamento de la reina Isabel de Castilla del 23 de noviembre de 1504 instaba que los indígenas fueran adoctrinados con dulzura contraponiéndose a las crueldades de los conquistadores: "No consientan ni den lugar a que los indios vecinos y moradores de las dichas islas y Tierrafirme ganados y por ganar, reciban agravio alguno en sus personas y bienes: manden que sean buen y justamente tratados". ${ }^{15}$ En las cartas enviadas al rey entre 1516 y 1518, los padres de la Orden de San Jerónimo en la Nueva Espańa proponían evangelizar a los indígenas con dulzura, mediante la nucleación y la "vida en policía":

Ahora entendemos en reducir los indios a poblaciones de hasta trescientos o cuatrocientos, que no anden vagos, sino en policia; se casen, tengan sus haciendas, pesquerías, monterías... $\mathrm{E}$ estaban tan al cabo cuando los PP. Jerónimos e yo llegamos, asi en la justicia como en todo lo otro que conviene al buen tratamiento de los indios. ${ }^{16}$

Para asegurar la conversión de los indígenas, estas disposiciones prohibían las "idolatrías", es decir, sacrificios humanos, entierros suntuosos, ofrendas a los dioses y borracheras. La prohibición ritual aparecía en las Reales Cédulas para Hernán Cortés de 1523 (y en la Real Cédula de 17 de noviembre de 1526), que ordenaba la destrucción sistemática de ídolos, templos y adoratorios y la prohibición de comer carne humana y hacer otras abominaciones contra la fe católica. ${ }^{17}$ Estas mismas Cédulas se ordenaba la forma y disposición de las "ciudades de españoles" que fueron trazadas usando "la regla y el cordel"; del espacio interno del poblado español, con la plaza, la iglesia y las casas; del ejido para el pastoreo y los baldíos alrededor de la ciudad estaría. Las nuevas fundaciones podrían expandirse a partir de la plaza, donde se localizarían las casas los principales y se festejarían las corridas de caballos.

Elijan el sitio de los que estuvieran vacantes y por disposición nuestra se pueda ocupar sin prejuicio de los indios y naturales o con su libre consentimiento y cuando hagan la planta del lugar repártanlo por sus plazas, calles y solares a cordel y regla, comenzando desde la plaza mayor y sacando desde ella las calles a las puertas y caminos principales, y dejando tanto compás abierto que aunque la población vaya en gran crecimiento se pueda siempre proseguir y dilatar en la misma forma. ${ }^{18}$

\footnotetext{
${ }^{14}$ PAREDES, Julián de, op. cit., Libro VI, título VIII, ley i.

${ }^{15}$ Ibid., Libro VI, título X, ley i.

${ }^{16}$ SERRANO, Manuel. Orígenes de la dominación española en América. In: Nueva Biblioteca de Autores Espańoles. Madridd: Casa editorial Bailly \& Bailliere, 1918; BREWER-CARÍAS, Allan. La Ciudad Ordenada: Estudio sobre "el orden que se ha de tener en descubrir y poblar" o sobre el trazado regular de la ciudad hispanoamericana, en particular, de las ciudades de Venezuela. Madridd: Ediciones Pascual Mandoz — Universidad Carlos III de Madridd, 1997, p. 413.

${ }^{17}$ PAREDES, Julián de, op. cit., Libro I, título I, ley vii.

${ }^{18}$ Ibid., Libro IV, título VII, ley i.
} 
Aunque las Instrucciones para Hernán Cortés de 1523 pueden considerarse como los principios del urbanismo en América para las "ciudades de españoles", con la plaza central, calles rectas y templo cristiano, esta ley no hace explícita la concentración de los indígenas. La legislación sólo advertía que los indígenas no deberían vivir "derramados", y prescribían su inclusión en las "ciudades de españoles", sin detallar cómo concentrarlos. La reducción como mecanismo para adoctrinar a los indígenas no estaba totalmente definido en la primera mitad del siglo XVI, aunque se generaba por oposición al patrón de asentamiento disperso que, según estas leyes, llevaba a la "ociosidad y malos vicios". La concentración inicial de la población indígena en América requería de un espacio adecuado: la iglesia. El Papa Alejandro VI concedió a los Reyes Católicos el Patronazgo Real y el privilegio de edificarlas en los territorios americanos, mediante la bula Inter Caetera de 1493. La Real Cédula de 10 de noviembre de 1528 confirmó este acuerdo:

Que en aquellas provincias se edificasen iglesias donde ofrecer sacrificio a Dios Nuestro Señor y alabar Su Santo Nombre, y propusieron a los sumos pontífices que le erigiesen catedrales metropolitanas, las cuales se erigieron y fundaron, dando para sus fabricas, dote, ornato y servicio del culto divino gran parte de Nuestra Real hacienda, como patronos de todas las iglesias metropolitanas, catedrales, colegiales, abaciales y todos los demás lugares píos, arzobispados, obispados, abadías, prebendas, beneficios y oficios eclesiásticos. ${ }^{19}$

Para materializar la presencia católica en América, el emperador Carlos V ordenó la construcción de iglesias para sustituir las casas de "idolatrías" en la Real Cédula del 2 de agosto de 1533:

Que en las cabeceras de todos los pueblos de indios [...] se edifiquen iglesias donde sean doctrinados y se les administren los Santos Sacramentos, y que para esto se aparte de los tributos que los indios hubieran de dar a nos y a sus encomenderos cada ańo lo que fueros necesario, hasta que las iglesias estén acabadas, con que no exceda de la cuarta parte de los dichos tributos. ${ }^{20}$

La Corona ordenó el adoctrinamiento masivo y compulsivo, bajo pena de pérdida de la población indígena encomendada, como estaba estipulado en las Cédulas Reales de 20 de noviembre de 1536 y de 10 de mayo $1554 .{ }^{21}$ Aun así, la falta de una reglamentación para reordenar el territorio indígena se evidencia en la Real Cédula del 1 de noviembre de 1536, que permite el uso de los patrones de asentamiento originales. La interdicción de la

\footnotetext{
${ }^{19}$ Ibid., Libro I, título II, ley i.

${ }^{20}$ Ibid., Libro 1, título II, ley vi.

${ }^{21}$ Ibid., Libro VI, título IX, ley iii; Libro VI, título IX, ley i. 
movilidad indígena y la regulación de las horas para escuchar la catequesis y del calendario para determinar los días sacros se convirtieron en los mecanismos iniciales para ejercer la doctrina, como lo ordenaba la Real Cédula del 30 de noviembre de $1537 .{ }^{22}$ Todavía la Real Cédula de 3 de agosto de 1538 mandaba únicamente que los indígenas se congregasen sin avisar cómo: "Para que los indios aprovechen más en cristiandad y policía, se debe ordenar que vivan juntos y concertadamente pues de esta forma los concedan sus prelados y atenderán mejor a su bien y doctrina”. ${ }^{23}$ La premisa mayor estas leyes era preservar al indígena sin ejercer la violencia, usando la catequesis y la reducción no planeada alrededor de la iglesia como mecanismo para la conversión, como explicaba la Real Cédula del 21 de marzo de 1551 a los gobernadores:

Que con mucha templanza y moderación ejecuten la reducción, población y doctrina de los indios, con tanta suavidad y blandura que sin causar inconveniente diese motivo a los que no se pudiesen poblar luego, y amparo de los ya reducidos, acudiesen a ofrecerle de su voluntad. ${ }^{24}$

Las disposiciones que pretendían suprimir los abusos de los españoles se basaban en las denuncias de religiosos como Bartolomé de las Casas. Entre las innumerables descripciones de la sevicia de los españoles, ${ }^{25}$ Manuel Serrano y Sanz describe en su obra Orígenes de la dominación española en América un suceso de violencia que debió presenciar este evangelizador dominico:

Y aconteció que mientras un capitán distribuía la comida a los españoles, cierto soldado, que debió de notar en los indios movimientos de hostilidad, sacó la espada y comenzó a dar tajos en aquéllos; como los estados psicológicos, especialmente el del miedo, son contagiosos, los demás le secundaron, y en breve tiempo fueron muertos o heridos no pocos indios. ${ }^{26}$

La repetición las prohibiciones contra los malos tratos y la esclavitud en las colonias en la ley durante la primera mitad del siglo XVI (Reales Cédulas de 1523, 1526, 1530, 1532, 1540, 1541, 1542 y 1543) advierte del uso excesivo de la violencia por parte de los espańoles para someter a los indígenas. A pesar de las prohibiciones, la predominancia de las crueldades y la esclavitud indígena en el Nuevo Mundo llevaron a que Bartolomé de las Casas se enfrentara a sus adversarios defensores de las Guerras Justas ${ }^{27}$ publicando en 1552 la Brevísima relación de

\footnotetext{
${ }^{22}$ Ibid., Libro I, título I, ley xii.

${ }^{23}$ Ibid., Libro VI, título I, ley xix.

${ }^{24}$ Ibid., Libro VI, título III, ley i.

${ }^{25}$ URIBE, Ángela. Perfiles del mal en la historia de Colombia. Bogotá: Universidad Nacional de Colombia, 2009.

${ }^{26}$ SERRANO, Manuel, op. cit., p. 339.

${ }^{27}$ LAFAYE, Jacques. Sangrientas fiestas del renacimiento: la era de Carlos V, Francisco I y Solimán (15001557). México: Fondo de Cultura Económica, 1999.
} 
la destrucción de las Indias. ${ }^{28}$ En 1550 el padre Jerónimo de San Miguel, primer provincial del Nuevo Reino de Granada, escribió una carta al rey informando la poca importancia que tenía la evangelización para la Real Audiencia de Santafé y narró los malos tratos contra los indígenas, que se manifestaban en forma de esclavitud, torturas, mutilaciones y muertes violentas. ${ }^{29}$ La transformación total del indígena como un nuevo ser mediante la "vida en policía" y la homogenización cultural se instalaba como proyecto regio y religioso en el Nuevo Mundo. La conquista, la sevicia y la codicia entraban en conflicto con el trato dulce, la nucleación y la misión evangélica. En este contexto, los "pueblos de indios" aparecían como estandartes simbólicos y pedagógicos de la religión católica, como nuevas comunidades de fe.

\section{La ciudad ordenada en la tradición española}

Aunque durante la primera mitad del siglo XVI hubo varias prescripciones urbanas para América, las Ordenanzas de descubrimiento, nueva población y pacificación de las Indias dadas por Felipe II, el 13 de julio de 1573, en el bosque de Segovia aparecen como el tratado definitivo de urbanismo hispánico idealizado, donde se recogen con minucia 80 años de experiencia fundadora en el Nuevo Mundo. ${ }^{30} \mathrm{El}$ fin de la Conquista y de las Guerras Justas proclamado en este documento significó la unificación y homogenización urbana del vasto Imperio español. Como mecanismo perfeccionado de sumisión, en los "pueblos de indios" se concentraban los nativos para evangelizarlos evitando la violencia, como se verifica en la repetición de términos como "paz", "caridad", "no hacer mal y daño" y "ni fuerza ni agravio" en las ordenes de reducción. ${ }^{31}$ Las Ordenanzas se amparaban bajo el Patronazgo Real en América según las Leyes 25, 26, 27 y 36, ${ }^{32}$ extendiendo y reiterando la orden de las Reales Cédulas 1528 y 1533 de edificar iglesias en los "pueblos de indios". El objetivo urbano y moral de las Ordenanzas aparece en la Ley 148: "Que los índios que les fueron encomendados se reduzgan a pueblos y en ellos edifiquen yglesias para que seam dotrinados y biban en policía”. ${ }^{33}$

Los "pueblos de indios" del Nuevo Mundo fueron imaginados como lugares pedagógicos, donde la experiencia sensorial definiría los comportamientos y costumbres de sus

\footnotetext{
${ }^{28}$ CASAS, Bartolomé de las. Brevísima relación de la destrucción de las indias. Madridd: Ediciones Cátedra, 1982.

${ }^{29}$ FRIEDE, Juan. Documentos inéditos para la historia de Colombia, v. IX-X (1547-1550). Bogotá: Academia Colombiana de Historia. 1960b. FRIEDE, Juan. Los Franciscanos en el Nuevo Reino de Granada y el movimiento indigenista del siglo XVI. Bulletin Hispanique, t. 60, n. 1, p. 5-29, 1958.

${ }^{30}$ BREWER-CARIAS, Allan, op. cit.

${ }^{31}$ PIQUERA, Ricardo. Antonio de Berrio y las Ordenanzas de 1573. Boletín de Americanistas, Barcelona, $\mathrm{n}$. 49, p. 233-243, 1999.

${ }^{32}$ MINISTERIO DE VIVIENDA. Transcripción de las Ordenanzas de descubrimiento, nueva población y pacificación de las Indias dadas por Felipe II, el 13 de julio de 1573, en el bosque de Segovia según el original que se conserva en el Archivo General de Indias de Sevilla. Madridd: Ministerio de Vivienda, 1976, p. 26-29, 36.

${ }^{33}$ Ibid., p. 112-113.
} 
habitantes. En la tradición urbanística europea la ciudad era el lugar de la interacción de quienes compartían una base moral. Deffontaines ${ }^{34}$ propuso comparar las ciudades "hipodámicas" españolas en América y las bastides edificadas entre 1240 y 1320 en el sur de Francia, comunidades configuradas para la protección ante los abusos de los señores feudales y la Cruzada contra los Cátaros (1209-1244). Algunos autores reconocen el carácter cristiano de las fundaciones españolas del siglo XIII, como el trazado regular católico en contraposición a la irregularidad urbana musulmana. ${ }^{35}$ Las ciudades al sur de España, como Málaga, Granada, Córdoba y Sevilla resaltaban por su estrechez y desorden urbano. En ellas fueron prohibidos los saledizos y cobertizos que entorpecían el paso de caballeros y coches: las nuevas ciudades privilegiaron la calle protegiéndola de la invasión de las casas. ${ }^{36}$ Entre los tratadistas humanistas que influyeron en el urbanismo español americano destaca el franciscano catalán Francesc Eiximenic (1340-1409), cuyo pensamiento moral y religioso alimentó las ideas políticas de los Reyes Católicos. ${ }^{37}$ La herencia urbana de Eiximenic proviene de ciudades ortogonales proyectadas y edificadas por Jaime I de Aragón (1208-1276), como Villareal de Burriana y Nules. ${ }^{38}$ En los escritos del fraile Eiximenic se vislumbraba la idea de la ciudad bella, noble y bien ordenada, que seguía en su forma el modelo de la Jerusalén Celestial. Consideraba además que la ciudad debía ser proyectada según una teoría urbana, concibiendo sus funciones intelectuales y simbólicas para alcanzar la virtud cristiana. Sería en la ciudad racional, zonificada y dispuesta dentro de un orden cósmico donde los súbditos del príncipe cristiano debían seguir comportamientos de personas virtuosas. ${ }^{39}$

Para iniciar el proceso de concentración de indígenas, las Ordenanzas describían en las Leyes 34, 35, 39 y 40 las cualidades del lugar para fundar el "pueblo de indios" según la abundancia de agua, de frutos, y de personas jóvenes y sanas, y la posición y fuerza de los vientos. ${ }^{40}$ Estos criterios para la elección del lugar aparecen desde el siglo XIV. En el capítulo CVI del duodécimo libro de su tratado Lo Crestià (1385-1392), ${ }^{41}$ el franciscano Francesc Eiximenic caracterizó el lugar propicio para la construcción de la ciudad, una amplia plani-

\footnotetext{
${ }^{34}$ DEFFONTAINES, Pierre. Como se constituiu no Brasil a rêde de cidades. Boletim Geográfico, Rio de Janeiro, n. 15, p. 298-308, 1944.

${ }^{35}$ VILA, Soledad. La ciudad de Eiximenis: Un proyecto teórico de Urbanismo en el siglo XIV. Valencia: Diputación Provincial de Valencia, 1984, p. 117.

${ }^{36}$ ANGUITA, Ricardo, op. cit.; SANTOS, Paulo. Formação de cidades no Brasil colonial. V coloquio internacional de estudos luso-brasileiros. Coimbra, 1968.

${ }^{37}$ GUARDA, Gabriel. Santo Tomás de Aquino y las fuentes del urbanismo indiano. Boletín de la Academia Chilena de la Historia, n. 72, p. 5-50, 1965; NAVARRO, María Isabel. Las fundaciones de ciudades y el pensamiento urbanístico hispánico en la era del descubrimiento. Scripta Nova, Barcelona, v. 10, n. 218 (43), 2006.

${ }^{38}$ VILA, Soledad, op. cit.

${ }^{39}$ ANTELO, Antonio. La ciudad ideal según fray Francesc Eiximenis y Rodrigo Sánchez de Arévalo. La Ciudad Hispánica siglos XIII al XVI (En la España Medieval, v. 6). Madrid: Editorial Universidad Complutense, p. 19-50, 1985.

${ }^{40}$ MINISTERIO DE VIVIENDA, op. cit., p. 34-39.

${ }^{41}$ EIXIMENIC, Francesc. Dotze del Crestià. Valencia: Lambert Palmart, 1484.
} 
cie para su expansión con abundantes fuentes de agua. Debían evitarse aquellos vientos que pudieran traer enfermedades y aprovechar los que purificaban el aire, ${ }^{42}$ lo que influía en la localización de hospitales, desagües, carnicerías y prostíbulos. ${ }^{43}$

Esta tradición humanista española continuó con la Suma de la Política escrita en 1454 por el castellano Rodrigo Sánchez de Arévalo (1404-1470), para quien el lugar elegido debía ser templado, ya que las personas de tierras calientes eran blandas e intelectuales mientras que las personas de tierras frías eran belicosas y amantes de los placeres. ${ }^{44}$ Por lo tanto, las personas que vivían en tierras calientes podían ser fácilmente súbditos, pues no tienen la audacia ni la fuerza para repeler sus enemigos. Para asegurar la salud de la población, la ciudad debía ser alineada con los vientos calientes del oriente y los gélidos del norte, que purificarían las pestilencia. Debían evitarse los vientos provenientes de lagunas y pantanos ${ }^{45}$ así como abastecer las ciudades con pozos estancados o fuentes con minerales. El agua debía ser clara y ligera, sin sabor ni olor, y las personas que la bebiesen debían mantener los dientes y las encías sanas. ${ }^{46}$

León Batista Alberti describía las mejores características de los lugares para construir las ciudades en el capítulo 4 del Libro I de su obra De re aedificatoria, ${ }^{47}$ de 1452 . El entorno debía ser preferiblemente templado, ${ }^{48}$ sin humedad excesiva ni muy seco: "tendrá el campo saludable, muy ancho, vario, deleitoso, fértil, fortalecido, lleno, adornado con abundancia de frutas y de fuentes, haya ríos, lagos y esté patente la oportunidad de la mar" ${ }^{49} \mathrm{El}$ arquitecto prohibió construir en los valles, pues la ciudad correría el riesgo de inundarse con lluvias; también advirtió evitar lugares con relámpagos frecuentes. Sugirió evitar las aguas estancadas o con barro, que serían criaderos de mosquitos, lombrices y enfermedades. Para Alberti el mejor criterio para fundar la ciudad era la buena salud de la población existente: "Si aquella región llevare copia de buenos frutos, si cría muchos viejos y de gran edad, si abundare de valiente y hermosa juventud, y de parto entero y muy ordinario". ${ }^{0}$

Pietro Cataneo (1510-1574) fue heredero de la tradición arquitectónica sienesa, en cuya obra I quattro primi libri di architettura (1554) ${ }^{51}$ describe la elección del sitio para la ciudad: "Debbesi per tanto nella elettione del suo sito ricercare, la sanità, la fertilità, la fortezza, la comomodità e la vaghezza, la sanità ci será porta dalla bontà dell'aria, dell'acque, e dell'herbe". ${ }^{52}$

\footnotetext{
${ }^{42}$ Ibid., f. 50r.

${ }^{43}$ Ibid., f. 52 r.

${ }^{44}$ SANCHEZ, Rodrigo. Suma de la política. Manuscrito Biblioteca Nacional de España, 1500?, ff. 13v-14r.

${ }^{45}$ Ibid., ff. 20v-22r.

${ }^{46}$ Ibid., ff. 22v-23r.

${ }^{47}$ LOZANO, Francisco. Los diez libros de arquitectura de Leon Baptista Alberto traduzidos de latin en romance. Madrid: Alonso Gómez impresor, 1582.

${ }^{48}$ Ibid., p. 11.

${ }^{49}$ Ibid., p. 110

${ }^{50}$ Ibid., p. 14

${ }^{51}$ CATANEO, Pietro. I quattro libri di architettura. Venecia: Aldus, 1554.

${ }^{52}$ CATANEO, Pietro, op. cit., f. 2r: Que por lo dicho anteriormente hay que, para la elección de su lugar
} 
Este arquitecto afirmaba que la temperatura y la pureza del aire eran determinantes para la salud de los ciudadanos, de modo que la dirección de los vientos era relevante para la fundación y su estructura, como era para Eiximenic y Alberti. Igualmente, prescribió buscar fuentes de agua fresca para abastecer la nueva ciudad y prohibió cualquier tipo de edificación dentro de los valles por razones defensivas y de salud.

Elegido el sitio para la fundación del "pueblo de indios", la proyección de éste según las Ordenanzas de 1573 debía iniciarse con el establecimiento de una plaza de la cual partían las calles principales, alineadas con "cuerda y regla", como aparece en la Ley 111 y que repite lo dispuesto en la Cédula a Hernán Cortés: "dexando tanto compas abierto que aunque la poblacion vaya en gran crecimiento se pueda siempre proseguir en la misma forma". 53 Las dimensiones de la plaza estaban especificadas en la Ley 113, según una proporción 2:3, pero cuya grandeza dependía del número de habitantes:

Se hará la eleción de la plaça teniendo respecto con que la población puede crecer no sea menor que 200 pies $^{54}$ en ancho y 300 de largo ni mayor de 800 pies de largo y 530 pies de ancho. De mediana y de buena proporción es de 600 pies de largo y 400 de ancho.55

La plaza rectangular serviría para las solemnidades de la ciudad, el cumplimiento del calendario religioso, las corridas de toros y otros eventos señoriales, y era el espacio donde giraba la vida urbana y se expresaban las relaciones de poder en América. La Ley 126 declaraba la preeminencia de los edificios públicos en el marco de la plaza: "En la plaça no se den solares para particulares dense para fabrica de la yglesia y casas reales y propios de la ciudad". ${ }^{56}$ Igualmente, las calles que partían de la plaza debían estar alineadas con los vientos principales y serían más anchas o estrechas dependiendo del clima, como estipulaba la Ley 114. ${ }^{57}$ Según las Ordenanzas, tras demarcar la plaza y las calles, la iglesia debía ser la primera y principal construcción del poblado, cuya preeminencia y visibilidad se lograba mediante el aislamiento y elevación del templo, como aparece consignado en la Ley $119 .{ }^{58}$ La Figura 1 muestra la interpretación de las Ordenanzas según Salcedo. ${ }^{59}$

buscar la sanidad, la fertilidad, la fortaleza, la comodidad y la grandeza, la sanidad nos será traída de la bondad del aire, del agua y del campo [Traducción propia].

${ }^{53}$ MINISTERIO DE VIVIENDA, op. cit., p. 82-85.

${ }^{54} 1$ pie equivale a 12 pulgadas o 0,28 metros. Por lo tanto, las medidas de las plazas serían: $56 \mathrm{~m} \times 84 \mathrm{~m}$ las menores; $112 \mathrm{~m} \times 168 \mathrm{~m}$ las medianas; $148 \mathrm{~m} \times 224 \mathrm{~m}$ las mayores.

${ }^{55}$ Ibid., p. 86-89.

${ }^{56}$ Ibid., p. 94-97.

${ }^{57}$ Ibid., p. 88-89.

${ }^{58}$ Ibid., p. $90-91$.

${ }^{59}$ SALCEDO, Jaime. Urbanismo Hispano-Americano siglos XVI, XVII y XVIII. El modelo urbano aplicado a la América española, su génesis y su desarrollo teórico y práctico. Bogotá: Centro Editorial Javeriano, 1994. p. 108. 
Figura 1

Interpretación de las Ordenanzas de 1573.

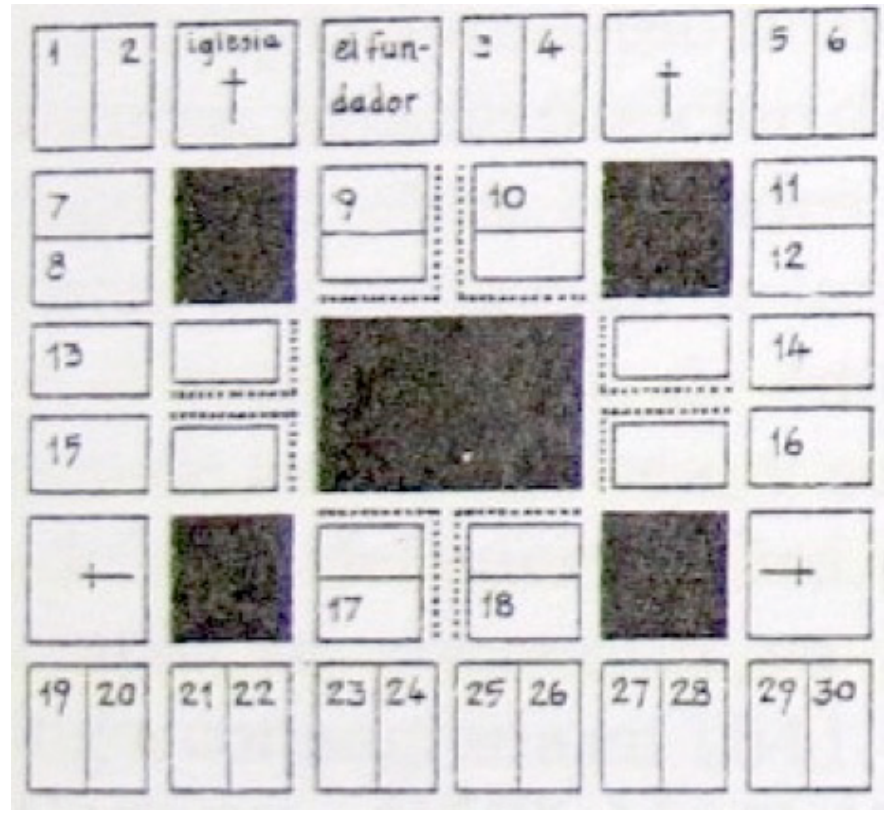

Doscientos años antes, en el capítulo CX de su obra Lo Crestia el franciscano Eiximenic aseveraba que la forma más bella y perfecta de la ciudad amurallada era la cuadrada. ${ }^{60} \mathrm{~A}$ partir de las entradas principales que se abrían en cada lado continuarían dos avenidas rectas de modo que la ciudad quedaba dividida en cuatro partes donde habitarían las personas dependiendo de su oficio. ${ }^{61} \mathrm{El}$ centro de la ciudad era dominado por la iglesia católica, núcleo religioso de la comunidad. ${ }^{62}$ En medio de cada cuartel principal debía construirse una plaza y el templo o monasterio de las cuatro ordenes mendicantes. El edificio fortificado del príncipe se localizaría en un costado. De esta forma, la ciudad se constituye a partir del diseño cristiano de la cruz, lo que hace de su trazado principal un elemento pedagógico para sus habitantes. El plano de esta ciudad (Figura 2) es reproducido por Soledad Vila a partir del diseño de Puig y Cadafalch. ${ }^{63}$

Para Alberti la ciudad estaba determinada por la muralla y el trazado de las calles principales debería guiarse por las edificaciones más importantes, como la iglesia, aunque para él la avenida ganaba destaque frente a las residencias: "Y también a la calle en la ciudad fuera que conviene que esté muy bien lastrada y del todo muy limpia, la adornaran los portales con iguales lineamientos, y de una y otra parte las casas iguales en línea y nivel”. ${ }^{64} \mathrm{El}$ cruce

\footnotetext{
${ }^{60}$ EIXIMENIC, Francesc, op. cit., f. 51v.

${ }^{61}$ Ibid., f. 51v.

${ }^{62}$ Ibid., f. $51 v$.

${ }^{63}$ VILA, Soledad, op. cit., p. 137.

${ }^{64}$ LOZANO, Francisco, op. cit., p. 248.
} 
Figura 2

La ciudad ideal de Eiximenic.

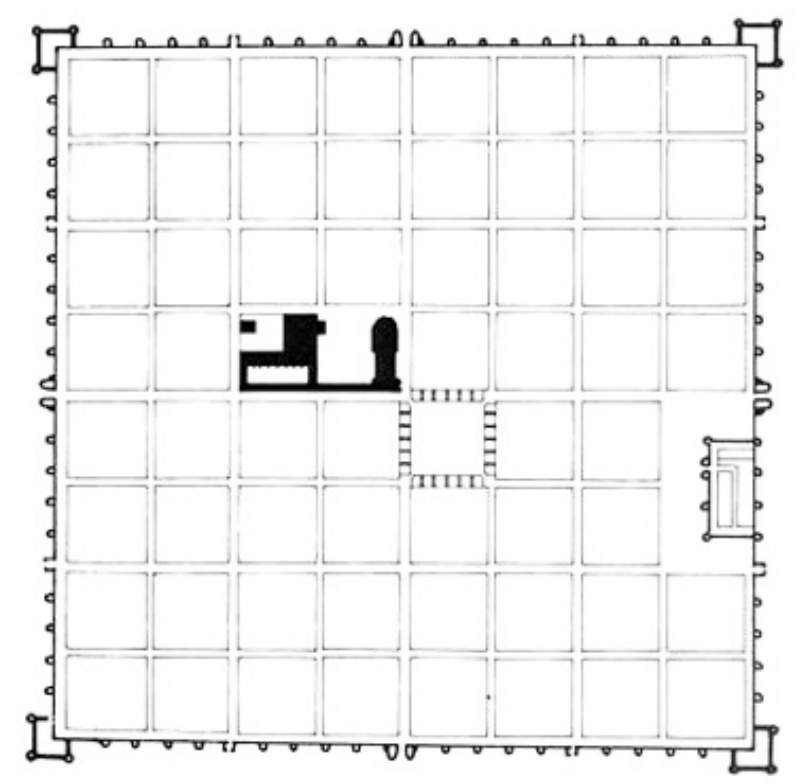

de las calles se ampliaba para formar las plazas, las cuales cumplirían diversas funciones, desde el ocio infantil y los juegos de esgrima hasta el encuentro de comerciantes y artesanos de diversos gremios. Las proporciones de las plazas eran de 2:3; y la altura máxima de los edificios a su alrededor era un tercio del ancho de ésta, para no opacar su grandeza. ${ }^{65}$ A pesar de estas disposiciones la plaza no definía la ciudad para Alberti ni se configuraba como un elemento esencial para su estructura, como sucedía con las murallas.

Inspirado en el libro de Alberti, Filarete describe en su Trattato di architettura ${ }^{66}$ de 1454 que el centro de la ciudad sería ocupado por una plaza rectangular cuyos edificios se distribuían así: al oriente la iglesia mayor, al occidental el palacio real, al norte la plaza de mercado y al sur la plaza de alimentos. También se localizaban en el marco de la plaza el palacio del capitán, la cárcel y la casa de la moneda. Las avenidas rectas unían la plaza con las entradas de la ciudad y eran recortadas por plazas menores para la venta de vino, paja, leña, granos y aceite, o para construir monasterios de las ordenes religiosas. Las avenidas debían hacerse inclinadas para mantener limpia la ciudad, de modo que al llover, o liberando agua desde la plaza, la suciedad sería barrida fácilmente hacia las puertas. ${ }^{67} \mathrm{El}$ plano de esta ciudad ideal (Figura 3) llamada Sforzida aparece en el Trattato di architettura de Filarete. ${ }^{68}$

\footnotetext{
${ }^{65}$ LOZANO, Francisco, op. cit., p. 247-254.

${ }^{66}$ FILARETE. Trattato di architettura. Milán: Il Polifilo, 1464.

${ }^{67}$ Ibid., f. 43r-44r.

${ }^{68}$ Ibid., f. 43r.
} 
Figura 3

Sforzinda, la ciudad ideal de Filarete.

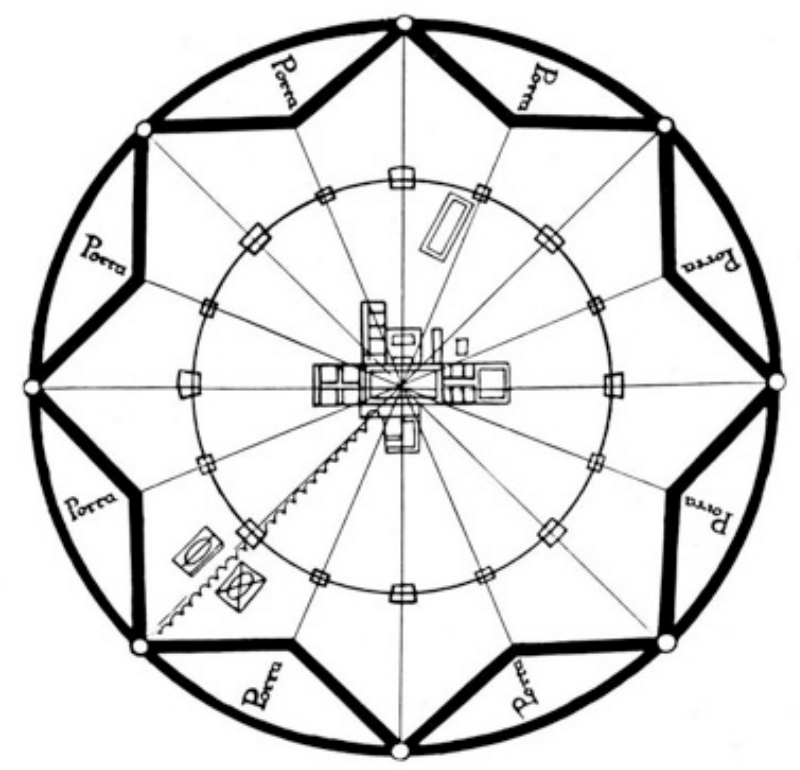

La obra de Cataneo se encuentra iluminada exhaustivamente con xilografías que ilustran las formas de la ciudad, gran carencia del texto de Alberti escrito un siglo antes. Para el sienes la plaza principal estaría en medio, en el cruce de las principales avenidas que atravesaban la ciudad de puerta a puerta. Ésta se adornaría con pórticos de magnificas columnas y a su alrededor deberían localizarse sólo los edificios públicos y no las residencias del príncipe y notables de la ciudad. ${ }^{69}$. Además de esta plaza, en las avenidas podrían abrirse plazas menores para el comercio y la recreación. ${ }^{70}$ La Figura 4 muestra la ciudad del príncipe con su cittadella pentagonal según un grabado de Cataneo. ${ }^{71}$

A diferencia del urbanismo militar europeo del siglo XVI, las Ordenanzas de 1573 fueron un tratado urbano "humanista" para América que pretendía imponer la paz rompiendo con la tradición bélica europea. La forma y adecuación de las murallas fueron un problema insistente para la defensa de las ciudades, mientras que los "pueblos de indios" fueron concebidos como las primeras ciudades abiertas para América. Para Eiximenic la muralla que circundaba la ciudad debía tener una puerta principal de entrada, fortificada mediante altas torres. $^{72}$ En el capítulo sexto de su obra Filarete describía cómo debía hacerse una ciudad, comenzando con la delimitación de las murallas, el castillo, las torres de entrada, el foso y las

\footnotetext{
${ }^{69}$ CATANEO, Pietro, op. cit., f. 8v.

${ }^{70}$ Ibid., ff. 7v-8r.

${ }^{71}$ Ibid., f. 20r.

${ }^{72}$ Ibid., f. 51v.
} 


\section{Figura 4}

La ciudad de Cataneo.

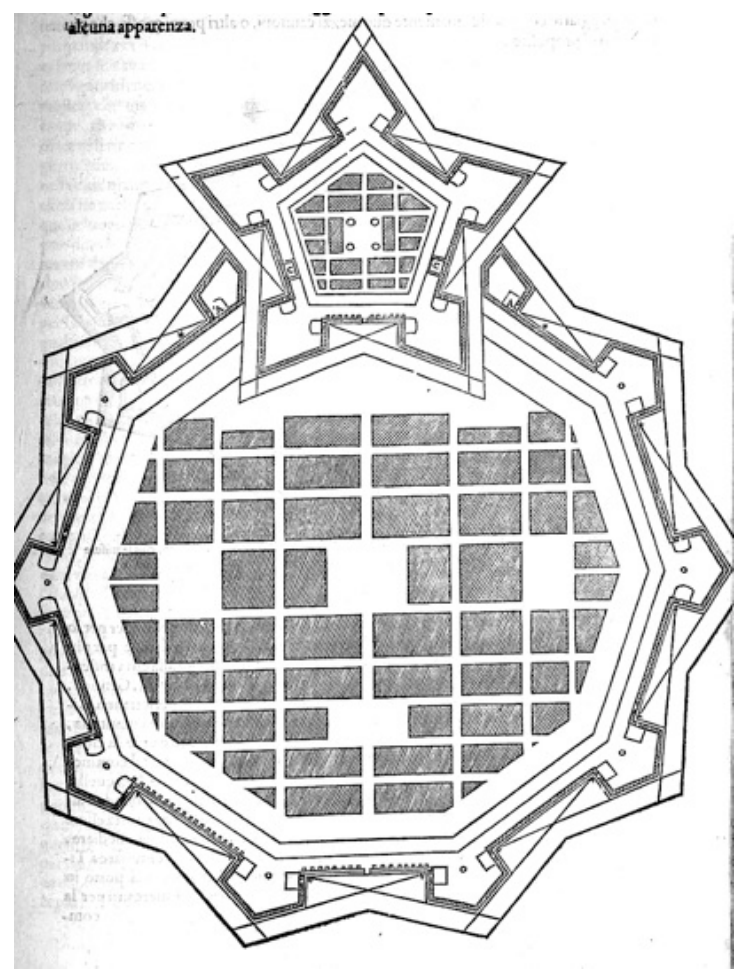

escaleras. Luego, con la aparición del baluarte como proyección de la muralla para sustentar la artillería defensiva, la geometría urbana se perfeccionó durante el siglo XVI, de modo que las consideraciones especulativas del renacimiento dieron paso a problemas empíricos de orden militar y economía de medios. ${ }^{73}$ Cataneo prescribía que las murallas debían ser angulares y su forma variada, dependiendo del tamaño e importancia de la nueva urbe y de la fuerza del enemigo. ${ }^{74}$

Al finalizar el siglo XVI esta separación entre las tendencias "humanista" y "defensiva" es más visible al observar la Politica para Corregidores y de dueños de vasallos en tiempos de paz $y$ de guerra de Jerónimo Castillo de Bovadilla de 1597 quien resaltaba las virtudes de estos funcionarios reales, modestia, sobriedad, adorno, imagen, prudencia y ciencia, así como sus funciones, atribuciones y relaciones con otros administradores. En el capítulo V del libro III, Castillo de Bovadilla se refería al cuidado de las obras de la ciudad: la grandeza de los edificios públicos, la necesidad de controlar el agua y el cuidado de las calles, como "hacer

\footnotetext{
${ }^{73}$ ISAC, Ángel. La ciudad militar en los tratados de fortificaciones del siglo XVI. In: La Ciudad Hispánica siglos XIII al XVI (En la España Medieval, v. 6). Madrid: Editorial Universidad Complutense, 1985. p. 51-63. ${ }^{74}$ CATANEO, Pietro, op. cit., f. 7 r.
} 
quitar los saledizos, que son cubiertas de ladrones y afean la ciudad". ${ }^{75}$ Entre otras obras buenas, este jurista promovía acabar todas las obras comenzadas y ensanchar plazas y calles de acuerdo con la riqueza de la ciudad; para esto el corregidor podía expropiar las construcciones aledańas para ampliar las plazas o realzar la belleza del templo cristiano. A continuación prescribía la limpieza de las calles, donde prohibía el paso de cerdos libres, estorbos e inmundicias, y artesanos callejeros como sastres, zapateros, herradores y bodegueros. Propuso cegar lagos y ríos que atravesasen la ciudad, pues atraerían la pestilencia, y prohibió que en lo alto del río que surtiese de agua fresca a la ciudad se curtieran cueros, se tomara bańo o se diera de beber a las bestias.

Esta tradición urbana "humanista" que relacionaba los criterios de fertilidad y abundancia para la selección del lugar, la rectitud de las calles y la centralidad de la Iglesia fue asimilada para América. Siguiendo la nueva idea de la ciudad abierta y en continuo crecimiento, la importancia edificatoria en el Nuevo Mundo se desplazó de la muralla al eje plaza/iglesia como lugar de cohesión y orden urbano y comunitario. La "policía" como máxima expresión de la vida en la ciudad debía materializarse pedagógicamente en la forma urbana ideal, en la que dominaba la rectitud y la limpieza. El lugar determinante de la iglesia dentro de los "pueblos de indios" complementaba sensorial el proceso de doctrina y transformación de comportamientos de los indígenas americanos.

\section{Los “pueblos de indios” y el proceso de reducción en el Nuevo Reino de Granada}

Los indígenas muiscas conformaban la población aborigen predominante del Nuevo Reino de Granada a la llegada del conquistador Gonzalo Jiménez de Quezada en 1536. Fray Pedro Simón narra en sus Noticias historiales de las conquistas de tierra firme en las indias occidentales de 1627 que el arribo de las huestes al Altiplano fue impulsado por la codicia de El Dorado, de las minas de sal de Nemocón, Zipaquirá y Nemuza, y de las esmeraldas de Somondoco. ${ }^{76}$ Los muiscas se asentaban siguiendo un patrón disperso, característico de varias jefaturas indígenas de América, ocupando el territorio alrededor de los "cercados" de los caciques locales según una estructura político-religiosa que ascendía hasta los caciques principales. Aunque el Zipa del sur y el Zaque del norte eran considerados las dos mayores títulos de la nación muisca, existían otros grandes caciques como Duitama, quien controlaba las rutas comerciales, y Sogamoso, sumo sacerdote de su religión heliolítica; otros cacicazgos considerados independientes dominaban el comercio

\footnotetext{
${ }^{75}$ CASTILLO, Jerónimo. Política para corregidores y señores de vasallos en tiempos de paz y de guerra. Madrid: Imprenta Real de la Gazeta, 1775, t. 2. p. 90.

${ }^{76}$ SIMÓN, Pedro. Noticias historiales de las conquistas de tierra firme en las indias occidentales. Segunda parte. Bogotá: Casa Editorial de Medardo Rivas, 1891.
} 
entre el río Magdalena y el Altiplano. Generalmente el cacicazgo y la casta sacerdotal eran heredadas por vía del tío materno. ${ }^{77}$

En el proceso de la Conquista los españoles mataron a los principales caciques muiscas conservando casi intactas las unidades menores de la jerarquía. En el nivel local, cada cacique tributario gobernaba una serie de capitanías, que podían ser mayores "sybyn" o menores "uta". Acompañando esta jerarquía política estaba la estructura religiosa, compuesta por sacerdotes "xeques" y niños sagrados "moxas" ${ }^{78}$ En las capitanías existían sacerdotes encargados de realizar las ofrendas en los templos "bubios", semejantes a los "lares" de la antigüedad. Además de estos templos estaban las casas santas "cucas", donde se guardaban los objetos para los rituales religiosos o para las grandes ceremonias públicas, como adornos elaborados con plumas de guacamayas, cráneos de jaguares, ofrendas en oro y tejidos finos. ${ }^{79}$ En cada capitanía había un pequeño adoratorio conectado cosmológicamente con la tierra y mediante el cual el capitán sustentaba parte de su poder. Los muiscas tenían amplias redes de relaciones entre los valles del Magdalena, la llanura del Orinoco y el Altiplano andino, con quienes comerciaban productos de tierras bajas como algodón, maní, ají y tabaco, y elementos rituales como hoja de coca, yopo (Anadenanthra peregrina), pieles de felinos, plumas exóticas y pepitas de oro. ${ }^{80}$ Los muiscas se especializaron en la producción según cada capitanía, como la fabricación de mantas finas, de vasijas de barro y de figuras de oro, cuya cantidad y belleza eran indicativos del poder y prestigio de los jefes.

El historiador Jaime Jaramillo Uribe ${ }^{81}$ expone las dificultades para determinar la cantidad de población muisca cuando llegaron los españoles, pues los cronistas solían exagerar o eran demasiado descriptivos, pues no se basaban en la contabilidad directa los cuerpos sino en conjeturas subjetivas y estimativas generales. Por ejemplo, el autor del Epitome de la Conquista presumía que en el campo de batalla habían 40.000 hombres del Zaque de Tunja y 60.000 del Zipa de Bogotá. ${ }^{82}$ En 1560 había aproximadamente 300 encomiendas con un promedio de 1.180 indígenas cada una, es decir, 350.000 indígenas siendo gobernador Jimé-

\footnotetext{
${ }^{77}$ FALCHETTI, Ana María; PLAZAS, Clemencia. El territorio de los muiscas a la llegada de los españoles. Cuadernos de Antropología 1, Bogotá: Universidad de Los Andes, 1973. p. 39-65; RAMIREZ, María Clemencia; SOTOMAYOR, María Lucía. Subregionalización del Altiplano Cundiboyacense: reflexiones metodológicas. Revista Colombiana de Antropología, Bogotá, v. 26, p. 174-201, 1986-1988; LONDOÑO, Eduardo. El lugar de la religión en la organización social muisca. Boletín del Museo del Oro, n. 40, p. 63-87, 1996.

${ }^{78}$ LONDOÑO, Eduardo, op. cit.; CORREA, François. El Sol del poder. Simbología y política entre los muiscas del norte de los Andes. Bogotá: Unibiblos, 2004.

${ }^{79}$ LONDOÑO, Eduardo, op. cit.

${ }^{80}$ LANGEBAEK, Carl Heinrik. Los caminos aborígenes: caminos, mercaderes y cacicazgos: circuitos de comunicación antes de la invasión española en Colombia. Caminos Reales de Colombia. Bogotá, Fondo FEN-Colombia, 1995. p. 35-45; LANGEBAEK, Carl Heinrik, Caminos del piedemonte oriental: sistemas de comunicación prehispánica entre los Andes orientales y el piedemonte llanero. Caminos Reales de Colombia. Bogotá, Fondo FEN-Colombia, 1995. p. 73-83.

${ }^{81}$ JARAMILLO, Jaime. La población indígena de Colombia en el momento de la conquista y sus transformaciones posteriores. Anuario colombiano de historia social y de la cultura, v. 2, 1964.

${ }^{82}$ FRIEDE, Juan, op. cit., 1960a
} 
nez de Quesada. Como la explotación del trabajo indígena se realizaba a través del tributo y el servicio personal, solamente los "indios útiles" importaban en las cuentas del Rey: varones entre 17 y 45 ańos con capacidad de pagar tributo. El grupo principal se complementaba con otras categorías de "indios no útiles": mujeres, niños, "reservados" (adolescentes), viejos, ausentes y "chusma" (enfermos). ${ }^{83}$ Para Jaramillo la Geografía y descripción universal de las Indias de Juan López de Velasco escrita en 1574 ofrece las cifras más precisas de la época: 52.000 indígenas por los encomenderos que vivían en Tunja, 40.000 en Santafé y 78.000 en el resto del Nuevo Reino de Granada, lo que evidenciaba que durante los primeros cuarenta ańos de conquista la población muisca disminuyó a casi la mitad, debido a las nuevas enfermedades, la violencia y los trabajos forzados para el pago del tributo. ${ }^{84}$ Finalmente, la relación del jesuita Alonso de Medrano de 1598 reportaba la existencia de 16 ciudades y 3 villas de españoles, e "innumerables pueblos de yndios fundados con sus yglesias doctrinas y govierno de corregidores españoles que los tienen sujetos y conquistados y con subordinacion alas dichas ciudades de españoles" ${ }^{85}$ Este jesuita calculaba la existencia de 40.000 tributarios entre los muiscas que se encontraban dispersos; en la ciudad de Santafé habrían 2.000 vecinos españoles y 20.000 indígenas que les servían; en Tunja habrían 3.000 vecinos y 20.000 indígenas a su servicio, mientras que en la ciudad de Sogamoso vivían 10.000 indígenas que practicaban la idolatría.

La nucleación de la población muisca fue una preocupación constante de la Corona española; una Carta Real de Carlos V del 9 de octubre de 1549 dirigida a los Oidores de la Real Audiencia de Santa Fé ${ }^{86}$ trataba de la necesidad de reducir con dulzura la población indígena:

Al bien de los naturales de esas partes y a su salvación convenía que se juntasen e hiciesen pueblos de muchas casas juntas en la comarca que ellos eligiesen, por que estando como están ahora una casa por sí, y aun cada barrio, no pueden ser doctrinados como convendría, ni promulgarle las leyes que se hacen en su beneficio, ni gozar de los sacramentos de la eucaristía y otras cosas de que se aprovecharían y valdrían estando juntos y no derramados [...] y que a todo lo susodicho debían ser los indios persuadidos por la mejor y más blanda y amorosa vía que ser pudiese, pues era todo en su provecho y beneficio. ${ }^{87}$

La Real Audiencia, máxima expresión de la justicia, fue creada como una forma de contrarrestar la desobediencia de los encomenderos e implementar las Ordenanzas en tierras americanas. Si bien el mandato de la Real Audiencia era la nucleación, ésta contradecía la

\footnotetext{
${ }^{83}$ JARAMILLO, op. cit.

${ }^{84}$ COLMENARES, op. cit.

${ }^{85}$ FRANCIS, Michael. Descripción del Nuevo Reino de Granada (1598) de Alonso de Medrano. Anuário Colombiano de Historia Social y Cultural, n. 30, p. 341-360.

${ }^{86}$ Instituida en 17 de julio de 1549.

${ }^{87}$ FRIEDE, Juan, op. cit., 1960b, t. X, p. 154-155.
} 
encomienda, que aprovechaba la dispersión de la población y se configuraba como la unidad de administración del territorio, de la mano de obra indígena y de la producción. Desde 1550 los frailes del Nuevo Reino de Granada se quejaban ante el Rey de que los indígenas eran forzados a trabajar únicamente en la encomienda, impidiendo la evangelización. ${ }^{88} \mathrm{El}$ franciscano Juan de los Barrios, primer obispo de Santafé, seńalaba en su texto de 1556 que la concentración era el modo más eficaz de adoctrinar los indígenas:

Y por que comúnmente los Yndios viven divididos, y separados en muchos Puebleçuelos, y seria gran trabaxo juntarlos en uno, para que oigan los dichos molestamos a los Sacerdotes asistan, y hagan Yglesia en los pueblos mayores, donde mas concurso aya, como queda dicho, y allí junten los hijos de sus feligreses, y les enseñes la doctrina christiana, e informes en las demás cosas de Nuestra Santa Fe Catholica, y como han de rezar cada día y quando se acuestan y levantan bendecir lo que comieren, y bebieren, y las demás buenas obras que los buenos christianos acostumbran hacer, enseñarles a leer y a escribir, contar y cantar, y sean los libros que leyeren devotos, y de sana doctrina. ${ }^{89}$

Se buscaba modificar el patrón de asentamiento disperso de los indígenas para hacer efectiva la evangelización y la introducción de la "vida en policía", como estaba prescrito en la Real Cédula de 1533 que obligaba a construir iglesias, aprovechando los lugares con mayor población indígena. A pesar de la orden de extirpación total de templos e idolatrías según la Real Cédula de 1523, el fraile Juan de los Barrios propuso levantar las nuevas iglesias en el lugar de los templos muiscas:

Mandamos que todos los santuarios [del demonio] que hubieren hechos en todos los pueblos donde ya hay algunos indios cristianos y lumbre de fe, sean quemados destruidos, sin hacer daño a sus personas ni haciendas y sean purgados aquellos lugares conforme al derecho y así mismo todos los ídolos que se hallaren, y si fuere lugar decente se haga allí una iglesia o a lo menos se ponga una cruz en señal de cristiandad. ${ }^{90}$

También aparecen en el texto los castigos para aquellos indígenas que aun realizaban los antiguos rituales tradicionales consideradas "diabólicos", donde se danzaba y se bebía chicha, fermento alcohólico del maíz. El obispo De los Barrios establecía el prohibición de las borracheras en el capítulo "De la policía, limpieza y orden de la iglesia y de otras cosas pertenecientes al buen gobierno de ella":

\footnotetext{
${ }^{88}$ PACHECO, Juan Manuel. La evangelización del Nuevo Reino siglo XVII (Historia extensa de Colombia, v. XIII, t. 2). Bogotá: Lerner; Academia Colombiana de Historia, 1971.

${ }^{89}$ ROMERO, Mario Germán. Fray Juan de los Barrios y la evangelización del Nuevo Reino de Granada. Bogotá: Academia Colombiana de Historia, 1960. p. 481.

${ }^{90}$ ROMERO, Mario Germán, op. cit., p. 465.
} 
Los indios así cristianos como infieles usan ritos y ceremonias antiguas en borracheras, bailes y supersticiones en gran ofensa a Dios Nuestro Señor, mandamos y ordenamos a nuestros ministros y alguaciles no lo consientan hacer y si lo hicieren los prendan y los traigan ante nos para que sean castigados conforme a derecho. ${ }^{11}$

La danza también fue prohibida por el obispo: "Que en las iglesias no se hagan danzas ni vigilias ni deshonestidades ni se junten a comer, ni jueguen ni hagan consejos ni pregonen cosas profanas en ellas siguiendo el ejemplo de Nuestro Redentor". 92 Aunque la prohibición de estos comportamientos estaba acompañada de la obligación de reducir a los "naturales" en pueblos, el obispo no propone una forma urbana ordenada sino prohibiciones a algunas costumbres religiosas.

Tras la publicación del texto de Juan de los Barrios, el licenciado Tomás López, oidor de la Real Audiencia de Santafé, estableció las Instrucciones que se ha de guardar en juntar y poblar los indios naturales de los términos de la ciudad de Pamplona en 1559. Ahí el oidor describió las mejores condiciones de sanidad y abundancia de agua del lugar, la plaza central, la iglesia al oriente, la casa del cacique al occidente y los demás predios que se repartirían entre la casa del Cabildo, la cárcel y otros demás principales. ${ }^{93}$ Luego, en su visita a los territorios de la provincia de Tunja de 1560, Tomás López ordenó la construcción de iglesias por cuenta de los encomenderos, ya que no habían templos ni religiosos suficientes para impartir la catequesis. ${ }^{94}$ La Real Audiencia expidió el Acuerdo del 13 de noviembre de 1565 apremiando a los encomenderos para fundar los "pueblos de indios": "Den orden como los naturales sean reducidos a pueblos grandes y se pueblen en forma de policía como los pueblos de españoles", 95 es decir, las ciudades de Santafé y Tunja.

El segundo obispo de Santafé, fray Luis Zapata de Cárdenas, ordenó en su Catecismo de 1576 la quema de los santuarios muiscas que perduraban y la persecución agresiva contra las prácticas de "idolatría”. Para Zapata de Cárdenas los santuarios debían ser extirpados desde la raíz, para acabar definitivamente con la memoria del lugar:

Por cuanto los santuarios son un tropiezo y estorbo para que los infieles se conviertan y ansimismo para que los nuevamente convertidos vuelvan a idolatrar, se manda que con toda solicitud y santo celo de la honra de Dios y bien de estos indios, los sacerdotes inquieran donde hay santuarios [...] para que se manden destruir y asolar del todo sin que haya memoria de ellos

\footnotetext{
${ }^{91}$ Ibid., p. 469.

${ }^{92}$ Ibid., p. 519.

${ }^{93}$ BREWER-CARIAS, Allan, op. cit., p. 26.

${ }^{94}$ COLMENARES, Germán, op. cit.; MUJICA, José. Relación de visitas coloniales: Pueblos, repartimientos y parcialidades indígenas de la provincia de Tunja y de los partidos de La Palma, Muzo, Vélez y Pamplona. Tunja: Publicaciones Academia Boyacense de Historia, 1948.

${ }_{95}$ ORTEGA, Enrique (Org.). Libro de Acuerdos de la Real Audiencia del Nuevo Reino de Granada 1557-1567. Bogotá: Archivo Nacional, 1947. p. 293-294.
} 
[...] Pareció ser más conveniente raer de la tierra totalmente la memoria de estos santuarios. ${ }^{96}$

Los pasos decisivos para la reforma del orden territorial fueron la quema y destrucción de los lugares rituales y la concentración de los indígenas. Para Zapata de Cárdenas la construcción de iglesias en el territorio muisca ayudaría en la conversión de sus almas:

Por cuanto el estar los indios congregados en pueblos es cosa tan necesaria para vivir política y cristianamente, que sin este fundamento no se hace cosa, mandase al sacerdote o religioso que no consienta que se despueble indio alguno y al que huyere lo reduzga por ministerio de los alcaldes del pueblo y alguaciles. ${ }^{97}$

El orden que se intentaba colocar en América hispánica necesitaba de la erradicación del antiguo sistema de creencias para imponer el cristianismo. La "policía" aparecía como una de las virtudes urbanas ligada a la fe cristiana y opuesta a las prácticas de "idolatría". El proceso de transformación cultural e imposición de las costumbres cristianas tardó décadas en implementarse, extendiéndose junto con las ideas religiosas como práctica de gobierno por los sacerdotes y funcionarios regios.

\section{Visitas de fiscalización religiosa y población en la segunda mitad del siglo XVI}

Luego de instituidas las Reales Audiencias en el territorio americano, fueron reglamentadas sus diferentes funciones durante el siglo XVI. Entre sus miembros el Oidor visitador fue el principal mediador e interprete in situ de la Corona según estaba consignado en la Real Cédula del 11 de junio de 1552:

Muchas veces se hacen las tasas de tributos por informaciones, sin estar presentes los visitadores ver ni reconocer los pueblos y su calidad, de que resultan inconvenientes. Mandamos, que los visitadores vean los pueblos por sus mismas personas y reconozcan el número de los indios y su posibilidad, para que con más justificación y entera noticia procedan. ${ }^{98}$

Las funciones del visitador fueron ampliadas con el tiempo, y al carácter fiscalizador se agregó la capacidad de hacer justicia y aplicar el castigo adecuado de inmediato. En la Real Cédula de 25 de mayo de 1566, el rey determinó con exactitud las funciones finales del visitador:

\footnotetext{
${ }^{96}$ LEE, Alberto; ROMERO, Mario Germán. Primer catecismo en Santa Fe de Bogotá: manual de pastoral diocesana del siglo XVI. Bogotá: Concejo Episcopal Latinoamericano, 1988. p. 38.

${ }^{97}$ Ibid., p. 31.

${ }^{98}$ PAREDES, Julián, op. cit., Libro VI, título V, ley xxvii.
} 
Por que nos sepamos cómo son regidos y gobernados nuestros vasallos y puedan más fácilmente alcanzar la justicia y tengan remedio y enmienda los daños y agravios que recibieren. Mandamos, que de todas y cada una de las Audiencias de las Indias salga un Oidor a visitar la tierra de su distrito y visite las Ciudades y pueblos y se informe de la calidad de la tierra y número de pobladores: y como podrán mejor sustentares: y las Iglesias y Monasterios que serán necesarios para el bien de los pueblos: y si los naturales hacen sacrificios y idolatrías de la gentilidad: como los corregidores ejercen sus oficios: y si los esclavos que sirven en las minas son doctrinados como deben: y si se cargan los indios o hacen esclavos, contra lo ordenado: y visite las boticas: y si en ellas hubiere medicinas corrompidas no las consienta vender, y haga derramar: y asimismo las ventas, tambos y mesones, y haga que tenga aranceles, y se informe de todo lo demás que conviniere. ${ }^{99}$

Además de sus atribuciones fiscales, el visitador podía reformar el territorio, de modo que aplicaba varias estrategias en diversos niveles para poder alcanzar el objetivo evangelizador. El registro visual de los visitadores debía ser complementado con las informaciones sigilosas suministradas por los evangelizadores y los caciques, para conocer sobre el cumplimiento de la catequización y del orden de la población, según la Real Cédula del 18 de julio de 1560:

El Oidor que saliere a visitar la tierra se informe de indios de la orden y forma que hay en la enseñanza de la Doctrina Cristiana, quien se la enseña, dice Misa, y administra los Santos Sacramentos de la Iglesia, y si en esto estuviera alguno en falta, que haga que se provea luego de todo lo conveniente: y asimismo se informe si tiene tasa de tributos, si se excede de ella en llevarles más de los que estuviese tasado, y si es excesiva y reciben otros daños, agravios y malos tratamientos, y de que personas, y si los obligan a llevar cargas, y hagan justicia y provean de forma que los indios queden desagraviados, guardando y ejecutando en todo las leyes y ordenanzas. ${ }^{100}$

El visitador actuaba como los ojos y oídos del Rey. La visita de mayor importancia para el ordenamiento territorial y la concentración de los muiscas en pueblos fue realizada por el Licenciado Luís Henríquez entre los años 1598 y 1604. Según Orlando Fals Borda ${ }^{101}$ el principal impulso para reducir los indígenas del Nuevo Reino de Granada en poblados fue instaurado por el Oidor Antonio González el 22 de septiembre de 1593, quien luego nombró a Andrés Egas de Guzmán como visitador. Tras la muerte de este último en 1598, Luis Henríquez continuó la política de nucleación compulsiva, siendo el responsable por los actos de población y localización de decenas de "pueblos de indios" e iglesias para la doctrina. Sólo en

\footnotetext{
${ }^{99}$ Ibid., Libro II, título XXXI, ley i.

${ }^{100}$ Ibid., Libro II, título XXXI, ley viii.

${ }^{101}$ FALS, Orlando. Indian Congregations in the New Kingdom of Granada: land tenure aspects, 1595-1850.

The Americas, Cambridge, v. 13, n. 4, p. 331-351, 1957.
} 
la Provincia de Tunja ordenó la nucleación en Sora, Cucaita, Samacá, Sáchica, Oicatá, Soracá, Cómbita, Chivatá, Boyacá, Motavita, Ramiriquí, Viracachá, Siachoque, Pesca, Iza, Cuitiva, Tópaga, Gámeza, Busbanza, Socotá, El Cocuy, Soata, Sativa, Duitama y Paipa durante seis ańos de visitas: en cada nuevo pueblo se reducirían tres encomiendas en promedio. ${ }^{102}$

En el caso del Nuevo Reino de Granada, la aplicación de las Ordenanzas de Felipe II implicó la jerarquización del espacio de los pueblos y del territorio. Como el territorio era considerado una sucesión de superficies bidimensional, las áreas inclinadas no fueron consideradas relevantes para los conquistadores. Esta concepción chocaba con el uso de los nativos americanos, quienes aprovechaban la variabilidad climática causada por la elevación del terreno en las zonas tropicales para conseguir una mayor variedad de productos alimenticios y de uso ritual. ${ }^{103}$ En su visita Henríquez encontró la población dispersa, algunas iglesias construidas con bahareque y paja y pocas de adobe con cimientos de piedra. ${ }^{104}$ Luego, determinó que los indígenas debían concentrarse en pueblos, localizados en lugares planos con abundancia de agua y madera, con buenas condiciones de temperatura y humedad. En otros casos, eligió entre varios asentamientos indígenas vecinos uno equidistante para que los muiscas pudieran atender los santos oficios sin necesidad de recorrer enormes distancias. A veces mandó mejorar las iglesias de paja y otras veces ordenó su traslado. Un ejemplo de cómo eligió el Oidor el lugar para concentrar los indígenas de varias encomiendas se encuentra en el auto de población de Boyacá:

Y para su conversión y aumento conviene se junten todos en un sitio, y consta que Boyacá es bueno, sano, enjuto y abundante de agua y leña, por tanto, mando que los dichos yndios pertenesçientes a Boyaca y sus parçialidades se recoxan, junten y puevlen en este sitio de Boyacá [...] y los de Pachaquira, Guatative y Soconsaque se junten y poblen y hagan sus casas y buhíos en el sitio mejor, más cómodo y llano y mas çercano a la yglesia de vahareque, cuvierta de paxa, donde al presente son doctrinados, poblándoles y señalándoles sus casas y solares y la tierra neçesaria por barrios y calles, con distinçión de cada puevlo. ${ }^{105}$

El Oidor establecía la fundación a partir del lote para la iglesia, frente a la que se abría el vacío de la plaza, uniendo estos dos elementos urbanos. Además, el Oidor proyectó la plaza cuadrada, ya fuera por comodidad o intentando homogeneizar el tamaño de los lotes.

${ }^{102}$ COLMENARES, Germán, op. cit.

${ }^{103}$ CORREA, François, op. cit.; SERJE, Margarita. The national imagination in New Granada. In: ERICKSON, Raymond; FONT, Mauricio A.; SCHWARTZ, Brian (Coord.). Alexander von Humboldt from the Americas to the Cosmos. Nova York: The Graduate Center, CUNY, 2004. p. 83-97.

${ }^{104}$ MUJICA, José, op. cit.; ROMERO, Guadalupe. Los pueblos de indios en Nueva Granada: trazas urbanas e iglesias doctrineras. Tesis (Doctorado en Historia del Arte) — Facultad de Filosofía y Letras, Universidad de Granada, Granada, 2008.

${ }^{105}$ ROMERO, Guadalupe, op. cit., p. 1.744-1.745. 
El tamaño de la plaza para los "pueblos de indios" era pequeño según las dimensiones de las Ordenanzas de 1573, siendo de 100 varas castellanas ${ }^{106}$ por cada lado. En este sentido se asemejaba a la ciudad de Eiximenic, aunque en las Ordenanzas estaba prescrito que la plaza debía ser rectangular para realizar las corridas de caballos. En la visita a Sáchica, uno de los primeros poblados donde se dirigió Henríquez, se presenta de manera sucinta el orden de los futuros poblados de la Provincia de Tunja:

Mando se pueblen alrededor de la dicha yglesia el caçique y capitanes de el para que sean bien doctrinados y vivan en pulitica (sic) española, dando a los caçiques a quarenta varas en quadro por frente y a los capitanes a treinta y a los yndios a veinte, de forma que entre cada ochenta baras de largo quepan quatro buhios que salgan a veinte varas en quadro por frente y luego tengan una calle de çinco varas en quadro, y entre cada quarenta varas que divide la quadra a de aver un callejon de dos varas, e para el dicho efeto se a de desmontar las dichas sarsas e tunales del dicho sitio que tiene al presente, y en lo llano y mejor y alrededor de la dicha yglesia halla la dicha poblaçon con las dichas calles e callejones. ${ }^{107}$

Alrededor de la plaza, junto con la iglesia debían ubicarse las casas del cura y de los caciques de cada repartimiento, luego los capitanes y "particulares". Esta repartición jerárquica contravenía tanto las prescripciones de las Ordenanzas de 1573, donde se estipulaba que lotes iguales se repartieran por suerte, como las proposiciones de Cataneo, quien localizó los edificios públicos en la plaza. El trazado de los "pueblos de indios" de Henríquez era jerarquizado mediante los tamaños de los lotes y su cercanía al epicentro sagrado. Las calles rectas, que debían permanecer limpias, tendrían espacio suficiente para el paso de los caballos y evitar la propagación del fuego. Como el pueblo era un espacio abierto, en espera de su futuro crecimiento, las calles terminaban en las tierras de labranza circundantes. El plano hipotético aproximado de un "pueblo de indios" de la Provincia de Tunja, ${ }^{108}$ tendría el templo dominando el espacio de la plaza, y la cuadrícula de las calles ordenando los lotes (Figura 5).

Henríquez también ordenó mejorar las condiciones del entorno: en Duitama ordenó la construcción de una acequia y canales para desviar los pequeños riachuelos que podían inundar la plaza y en Ramiriquí mandó a construir puentes que atravesaran el río Boyacá para agilizar el desplazamiento de los indígenas feligreses. Por otra parte, dispuso interdicciones hacia pueblos diferentes de los designados para recibir la doctrina. Esto implicó un reordenamiento de las viviendas indígenas para la evangelización, descomponiendo las redes sociales y familiares locales, y prohibiendo las peregrinaciones a lugares de culto an-

\footnotetext{
${ }^{106}$ Una vara castellana equivale a 0,86 metro.

${ }^{107}$ ROMERO, Guadalupe, op. cit., p. 2.652.

${ }^{108}$ Elaborado a partir de ROMERO, Guadalupe, op. cit.
} 


\section{Figura 5}

Plano hipotético del trazado urbano de los pueblos de indios.

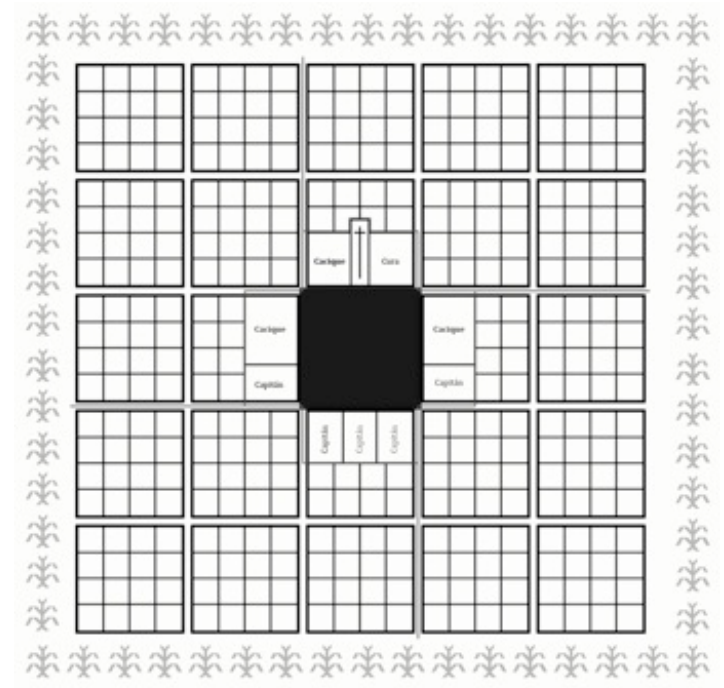

cestral, como Sogamoso. Finalmente, Henríquez dispuso quemar las casas dispersas, como complemento de la nucleación; esta orden de supresión fue reiterada al final de cada auto de población, como aparece en la visita de Samacá de 1598:

Saquen todos los dichos yndios, quemandoles sus bohios, sacandoles ante todas cosas lo que tuvieren dentro y porque esto no a vastado otras vezes les mando les arranquen qualesquier lavranças que tuvieren y den aviso a los vezinos españoles sircunvezinos se las arranquen y coman con sus ganados y no les consientan estar en las sobre quevradas fuera aquellas que caen en los resguardos y comunidades por su merçed señaladas y en qualquier dia, parte donde hallen piedra de moler y buhio le puedan quemar aunque este en el dicho resguardo, dejando las lavranças enteras porque la povlaçon solo a de ser en los sitios señalados. ${ }^{109}$

La quema de viviendas complementada con la destrucción de la labranza por medio del ganado pretendía borrar con la apropiación ancestral productiva y reproductiva del territorio. Se trasladaba además una práctica de destrucción templos hacia la cotidianidad, que interfería en la cultura muisca al marcar los espacios permitidos y prohibidos para vivir y labrar.

Siendo el templo el epicentro de los "pueblos de indios", la observación de su construcción fue una constante preocupación durante el siglo XVII como espacio pedagógico y de encuentro con la divinidad. Algunos elementos característicos de la vida en "policía” y del urbanismo "humanista" aquí descrito prevalecen en estos "pueblos de indios" edificados para la doctrina: la iglesia central como eje de fundación, la plaza cuadrada frente a la igle-

${ }^{109}$ Ibid., p. 2.921. 
sia, los lotes en cuadrícula que se extienden jerárquicamente desde la plaza y las calles rectas y limpias. Durante la primera mitad del siglo XVII fueron entregadas algunas iglesias que Henríquez mando a erigir: Chivatá en el año 1605 y Duitama en 1613; en Pesca estaban los muros faltando el maderamen para el tejado en 1608; en Paipa estaba incompleta y con la madera para la armadura pudriéndose en 1619; en Sativa estaba sin terminar en 1630; en Viracachá y Ramiriquí solo estaban los fundamentos de piedra en 1622, igual que en El Cocuy en $1635 .{ }^{110}$ Aunque el proceso de concentración y población demoraron todo el siglo XVII para consolidarse, para el final de la Colonia todos los pueblos mencionados estaban edificados alrededor de la plaza.

\section{Consideraciones finales}

La genealogía de las formas urbanas expuesta en este artículo muestra una estrecha relación entre la morfología de la ciudad con la moral y los comportamientos de sus habitantes. Eiximenic idealizó la ciudad cuadrada perfecta para la defensa, una comunidad armónica donde cada integrante tenía una función; dos siglos después algunas de estas ideas "humanistas" estuvieron presentes en los "pueblos de indios" ortogonales y abiertos que ordenó construir Henríquez en la Provincia de Tunja. Las formas de la ciudad ideal respondían a las necesidades sociales: en Europa fueron diseñadas para la fortificación y en el Nuevo Mundo fueron concebidas como mecanismos de doctrina. El carácter pedagógico de la ciudad hispanoamericana y la comunidad que la habitaba requería una expresión material determinada, como la rectitud de las calles y la austeridad, consideradas virtudes urbanas y morales, que se mantuvieron en las formas urbanas "humanistas" con notable rigidez. En estos "pueblos de indios" se expresaron las tradiciones urbanísticas católicas, con interpretaciones y modificaciones que buscaban la simplicidad formal y la expresividad jerárquica y cosmológica de la religión que los españoles deseaban imponer.

Los procesos de doctrina y nucleación de la población indígena estaban ligados en la legislación española. Imponer una nueva fe implicaba determinar una nueva forma de vida mediante los "pueblos de indios", cuyos elementos constitutivos, iglesia, plaza y trazado ortogonal que evocaba la cruz, se fundieron como principio fundador de la vida en "policía" y como un mecanismo para el control de la población. La iglesia era el punto de partida, escenario para consolidar el proceso de evangelización y ordenar los comportamientos de los indígenas. La plaza, plana y cuadrada, sintetizaba el lugar para las actividades públicas, y desde donde se desdoblaban las jerarquías sociales. El complejo plaza/iglesia, que está presente en toda esta tradición "humanista" se fusionó en los "pueblos de indios", configurándose como el emblema mínimo de la sociedad española en América. 
Los "pueblos de indios" fueron una extensión del poder del rey y de la iglesia, el lugar para someter corporal y espiritual a los muiscas y conformar "ex novo" una comunidad que perdía paulatinamente sus lazos telúricos. La destrucción de las "idolatrías" y de las "casas de los rebeldes" aparecen como el substituto político de las murallas: si en Europa se priorizaba la actitud de guerra y defensa contra el invasor, en América los españoles priorizaban la pacificación y la destrucción sistemática de todo lo contrario a la tradición. La prohibición y persecución de las costumbres consideradas "salvajes" como el sacrificio ritual, y la destrucción templos y casas fueron prácticas de gobierno y de control del territorio que complementaban la construcción de los "pueblos de indios" y el trato "bondadoso". Se creaba una duplicidad en el cuerpo del indígena, que podía ser rechazado por vicioso e impúdico, pero que debía ser salvado mediante la conversión. Con la creación de los "pueblos de indios", el proyecto cultural español se volvió integral: transformaría el alma, el cuerpo y el territorio indígena. Aunque este proyecto de concentración no se realizó completamente, las pautas de comportamiento fueron sustancialmente modificadas, siendo el catolicismo la religión predominante en la actualidad. Así, los "pueblos de indios" pueden ser vistos como un mecanismo que complementó el proceso de sumisión y conversión de las almas, ayudando a configurar una comunidad moral y espiritual con el paso de los siglos.

\section{Fuentes primarias}

ACOSTA, Joseph de. Historia Natural y Moral de las Indias. Madrid: Ramón Anglés, 1894. CASAS, Bartolomé de las. Brevísima relación de la destrucción de las Indias. Madrid: Ediciones Cátedra, 1982.

CASTILLO DE BOVADILLA, Jerónimo. Politica para corregidores y señores de vasallos en tiempos de paz y de guerra. Madridd: Imprenta Real de la Gazeta, 1775.

CATANEO, Pietro. I quattro libri di architettura. Veneza: Aldus, 1554.

COVARRUBIAS, Sebastián. Tesoro de la lengua castellana o española. Madrid: Luis Sánchez impressor, 1611.

DICCIONARIO DE AUTORIDADES, t. V, 1737.

EIXIMENIC, Francesc. Dotze del Crestià. Valencia: Lambert Palmart, 1484.

FILARETE. Trattato di architettura. Milán: Il Polifilo, 1464.

FRANCIS, Michael. Descripción del Nuevo Reino de Granada (1598) de Alonso de Medrano. Anuário Colombiano de Historia Social y Cultural, n. 30, p. 341-360, 2003.

FRIEDE, Juan. Los Franciscanos en el Nuevo Reino de Granada y el movimiento indigenista del siglo XVI. Bulletin Hispanique, t. 60, n. 1, p. 5-29, 1958. 
FRIEDE, Juan. Descubrimiento del Nuevo Reino de Granada y Fundación de Bogotá (15361539). Bogotá: Imprenta del Banco de la República, 1960a.

FRIEDE, Juan. Documentos inéditos para la historia de Colombia, v. IX-X (1547-1550). Bogotá: Academia Colombiana de Historia, 1960b.

LOZANO, Francisco. Los diez libros de arquitectura de León Baptista Alberto traduzidos de latin en romance. Madridd: Alonso Gómez impresor, 1582.

MINISTERIO DE VIVIENDA. Transcripción de las Ordenanzas de descubrimiento, nueva población y pacificación de las Indias dadas por Felipe II, el 13 de julio de 1573, en el bosque de Segovia según el original que se conserva en el Archivo General de Indias de Sevilla. Madrid: Ministerio de Vivienda, 1976.

MUJICA SILVA, José. Relación de visitas coloniales: Pueblos, repartimientos y parcialidades indígenas de la provincia de Tunja y de los partidos de La Palma, Muzo, Vélez y Pamplona. Tunja: Publicaciones Academia Boyacense de Historia, 1948.

ORTEGA RICAURTE, Enrique (Org.). Libro de Acuerdos de la Real Audiencia del Nuevo Reino de Granada 1557-1567. Bogotá: Archivo Nacional, 1947.

PAREDES, Julián de. Recopilación de las Leyes de los Reinos de las Indias. Madrid, 1681.

ROMÁN Y ZAMORA, Jerónimo. Repúblicas de Indias idolatrías y gobierno en México y Perú antes de la conquista. Madrid: Victoriano Suárez editor, 1897.

ROMERO, Guadalupe. Los pueblos de indios en Nueva Granada: trazas urbanas e iglesias doctrineras. Tesis (Doctorado en Historia del Arte) — Facultad de Filosofía y Letras, Universidad de Granada, Granada, 2008.

ROMERO, Mario Germán. Fray Juan de los Barrios y la evangelización del Nuevo Reino de Granada. Bogotá: Academia Colombiana de Historia, 1960.

SANCHEZ DE AREVALO, Rodrigo. Suma de la politica. Manuscrito Biblioteca Nacional de España. 1500?

SERRANO Y SANZ, Manuel. Orígenes de la dominación española en América. (Nueva Biblioteca de Autores Españoles). Madrid: Casa editorial Bailly \& Bailliere, 1918.

SIMÓN, Pedro. Noticias historiales de las conquistas de tierra firme en las Indias occidentales. Segunda parte. Bogotá: Casa Editorial de Medardo Rivas, 1891.

\section{Referências bibliográficas}

ANGUITA CANTERO, Ricardo. Ordenanza y policia urbana, origenes de la reglamentación edificatoria en España. Granada: Universidad de Granada, 1997. 
ANTELO IGLESIAS, Antonio. La ciudad ideal según fray Francesc Eiximenis y Rodrigo Sánchez de Arévalo. La Ciudad Hispánica siglos XIII al XVI (En la España Medieval, v. 6). Madrid: Editorial Universidad Complutense, 1985.

BREWER-CARÍAS, Allan. La Ciudad Ordenada: Estudio sobre "el orden que se ha de tener en descubrir y poblar" o sobre el trazado regular de la ciudad hispanoamericana, en particular, de las ciudades de Venezuela. Madrid: Ediciones Pascual Mandoz; Universidad Carlos III de Madridd, 1997.

COLMENARES, Germán. La provincia de Tunja en el Nuevo Reino de Granada. Tunja: Publicaciones Academia Boyacense de Historia, 1984.

CORREA, François. El Sol del poder. Simbología y política entre los muiscas del norte de los Andes. Bogotá: Unibiblos, 2004.

DEFFONTAINES, Pierre. Como se constituiu no Brasil a rêde de cidades, Boletim Geográfico, Rio de Janeiro, n. 15, p. 298-308, 1944.

FALCHETTI, Ana María; PLAZAS, Clemencia. El territorio de los muiscas a la llegada de los espańoles. Cuadernos de Antropología 1. Bogotá: Universidad de Los Andes, 1973. p. 39-65.

FALS BORDA, Orlando. Indian Congregations in the New Kingdom of Granada: land tenure aspects, 1595-1850. The Americas, Cambridge, v. 13, n. 4, p. 331-351, 1957.

FRAILE, Pedro. "Razón, estado, ciudad y territorio: de Sinapia a Valentin de Foronda". Scripta Nova, Barcelona, v. 16, n. 418 (17), s/p, 2012.

GUARDA, Gabriel. Santo Tomás de Aquino y las fuentes del urbanismo indiano. Boletín de la Academia Chilena de la Historia, Santiago de Chile, n. 72, p. 5-50, 1965.

ISAC MARTINEZ, Ángel. La ciudad militar en los tratados de fortificaciones del siglo XVI. La Ciudad Hispánica siglos XIII al XVI (En la España Medieval, v. 6). Madrid: Editorial Universidad Complutense, 1985. p. 51-63.

JARAMILLO, Jaime. La población indígena de Colombia en el momento de la conquista y sus transformaciones posteriores. Anuario colombiano de historia social y de la cultura, Bogotá, v. 2, 1964.

LAFAYE, Jacques. Sangrientas fiestas del renacimiento: la era de Carlos V, Francisco I y Solimán (1500-1557). México: Fondo de Cultura Económica, 1999.

LANGEBAEK, Carl Heinrik. Caminos del piedemonte oriental: sistemas de comunicación prehispánica entre los Andes orientales y el piedemonte llanero. In: MORENO, Pilar; MELO, Jorge Orlando (Orgs.). Caminos Reales de Colombia. Bogotá: Fondo FEN-Colombia, 1995. p. 73-83.

LANGEBAEK, Carl Heinrik. Los caminos aborígenes: caminos, mercaderes y cacicazgos: circuitos de comunicación antes de la invasión española en Colombia. In: MORENO, Pilar; 
MELO, Jorge Orlando (Orgs.). Caminos Reales de Colombia. Bogotá: Fondo FEN-Colombia, 1995. p. 35-45.

LEE LOPEZ, Alberto; ROMERO, Mario Germán. Primer catecismo en Santa Fe de Bogotá: manual de pastoral diocesana del siglo XVI. Bogotá: Concejo Episcopal Latinoamericano, 1988.

LONDOÑO, Eduardo. El lugar de la religión en la organización social muisca. Boletin del Museo del Oro, Bogotá, n. 40, p. 63-87, 1996.

MORSE, Richard. A evolução das cidades latino-americanas. Cadernos CEBRAP, São Paulo, n. 22, 1975.

MORSE, Richard. A prolegomenom to Latin America urban history. The Hispanic American Historical Review, Durham, v. 52, n. 3, p. 359-394, 1972.

NAVARRO SEGURA, María Isabel. Las fundaciones de ciudades y el pensamiento urbanístico hispánico en la era del descubrimiento. Scripta Nova, Barcelona, v. X, n. 218 (43), 2006.

PACHECO, Juan Manuel. La evangelización del Nuevo Reino siglo XVII (Historia extensa de Colombia, v. XIII, t. 2). Bogotá: Lerner; Academia Colombiana de Historia, 1971.

PIQUERA, Ricardo. Antonio de Berrio y las Ordenanzas de 1573. Boletin de Americanistas, Barcelona, n. 49, p. 233-243, 1999.

RAMIREZ, María Clemencia; SOTOMAYOR, María Lucía. Subregionalización del Altiplano Cundiboyacense: reflexiones metodológicas. Revista Colombiana de Antropología, Bogotá, v. 26, p. 174-201, 1986-1988.

ROMERO, José Luis. América Latina, as cidades e as ideias. Rio de Janeiro: Editora UFRJ, 2009.

SALCEDO, Jaime. Urbanismo Hispano-Americano siglos XVI, XVII y XVIII. El modelo urbano aplicado a la América española, su génesis y su desarrollo teórico y práctico. Bogotá: Centro Editorial Javeriano, 1994.

SANTOS, Paulo. Formação de cidades no Brasil colonial. V coloquio internacional de estudos luso-brasileiros, Coimbra, 1968.

SERJE, Margarita. The national imagination in New Granada. In: ERICKSON, Raymond; FONT, Mauricio A.; SCHWARTZ, Brian (Coord.). Alexander von Humboldt from the Americas to the Cosmos. Nova York: The Graduate Center, CUNY, 2004. p. 83-97.

URIBE, Ángela. Perfiles del mal en la historia de Colombia. Bogotá: Universidad Nacional de Colombia, 2009.

VILA, Soledad. La ciudad de Eiximenis: Un proyecto teórico de Urbanismo en el siglo XIV. Valencia: Diputación Provincial de Valencia, 1984. 